\title{
Achieving Food Safety: A Case Study on Import Food Monitoring of Japan
}

\author{
Wai Yee Lin", Masahiro Yamao, Michiko Amano \\ Department of Bioresource Science, Graduate School of Biosphere Science, Hiroshima University, Japan \\ *Corresponding Author: waiyeelin@gmail.com
}

Copyright (C) 2016 by authors, all rights reserved. Authors agree that this article remains permanently open access under the terms of the Creative Commons Attribution License 4.0 International License

\begin{abstract}
This study is to examine how a country with a significant amount of import food like Japan achieves food safety. Desktop analysis, correlation analysis and in depth-interview at field surveys were employed. It is found that food legislation and regulatory framework of Japanese import food monitoring system supported and guided the responsibilities of food authority, private inspection and testing agencies and importers. A strong negative correlation is found between consultation at quarantine stations and violations of import food with $r$ value $=$ -0.77 .Even though the number of delegated laboratories in 62 foreign countries was 42 times higher than that of the domestic laboratories, they shared only $10 \%$ of total testing. Japanese Import food monitoring in export countries revealed less advantage in scope, if compared with the EU's system. Japan chooses not to rely on monitoring of export country solely rather than giving consultation to exporters and importers. The national standard formulation method is based on risk analysis in accordance with internationally accepted norms. It can conclude that Japan's import food monitoring system is streamlined in accordance with global trend. The food authority of Japan takes continuous restructuring with sound national quality infrastructure aimed at protection of consumers against adulterated import food.
\end{abstract}

Keywords Food Control, Monitoring, Inspection, Food Trade

\section{Introduction}

Ensuring safety of import food is as important as ensuring the safety of domestically produced food. At the national level, food authority executes import food monitoring as an important part of food control for protecting consumers against adulterated food. For the prevention of dumping of lesser quality foods, World Trade organization (WTO) member countries are free to choose high Sanitary and Phytosanitary (SPS) standard level. They can show the need of high level protection using risk assessment based on science and they have the right to take the SPS measures within their own sovereignty [19]. Kenney suggested that a strong import control system needs to be supported by import related data in preventing the dumping of lesser quality foods [8] so as to carry out necessary measures efficiently.

Food safety standards and technical requirements differ across markets. The requirements of European Union EU markets are based on EU directives for food safety and sanitation, US market based on United States Food and Drug Administration's regulations and Japanese market based on Food and Sanitation Law [4]. Among countries, food control system of EU is at the forefront in developing food safety standards and has a profound influence on the development of food export industry [7]. However, the optimum type of the system for one country may not be appropriate for another [6].

Japan is an important market for export countries, as two thirds of food intake on calorie basis relies on import. It was stressed that Japanese consumers are very worried about "the efficiency of the import inspection system" [17] because of the expanding food import since 1970s [20]. Fish \& fishery products and fruits \& vegetables are two major food groups rejected mainly for bacterial contamination and drug residues [18]. Major food export countries to Japan are USA with $29 \%$ of all import food into Japan, China with $11 \%$, Australia 7\% and Canada 6.76\% [1]. Therefore, this study will focus on Japanese import food monitoring and inspection so as to examine how a country like Japan with significant import of food and agricultural products achieves food safety and to compare Japanese import food monitoring system with that of EU's system.

\section{Methodology}

Surveys in Japan were performed at a private inspection corporation and at a public quarantine station. The first survey was conducted at Japan Frozen Food Inspection Corporation (JFFIC), one of the five largest private inspection institutions of Japan in November 2014.Short 
surveys were carried out twice at JFFIC situated in Kobe. The second survey was conducted in July 2015 at Hiroshima Quarantine Station under the Ministry of Health, Labor and Welfare (MHLW).The Hiroshima Quarantine Station is one of the 13 stations that gives consultation for food trade.

Both qualitative and quantitative methods were used to assess the food control system of Japan mainly focusing on import food monitoring for safety. This study employed three methods: desktop analysis, correlation analysis and interviews at field surveys with two levels: public and private levels in Japan. Intensive desktop analysis was done using rigorous literature review of available documents or reports of related institutions of food safety program of Japan and EU. The correlation analysis was made between consultation for import food monitoring and reduced violation rate to observe the efficiency of the import food monitoring system. It was also used to examine the number of inspection at port of arrival compared to that of declaration so as to support the discussion.

\section{Result and Discussion}

This section is divided into two, Japanese import food monitoring system and a specific comparison of import food monitoring in export country of EU and Japan.

DOMESTIC

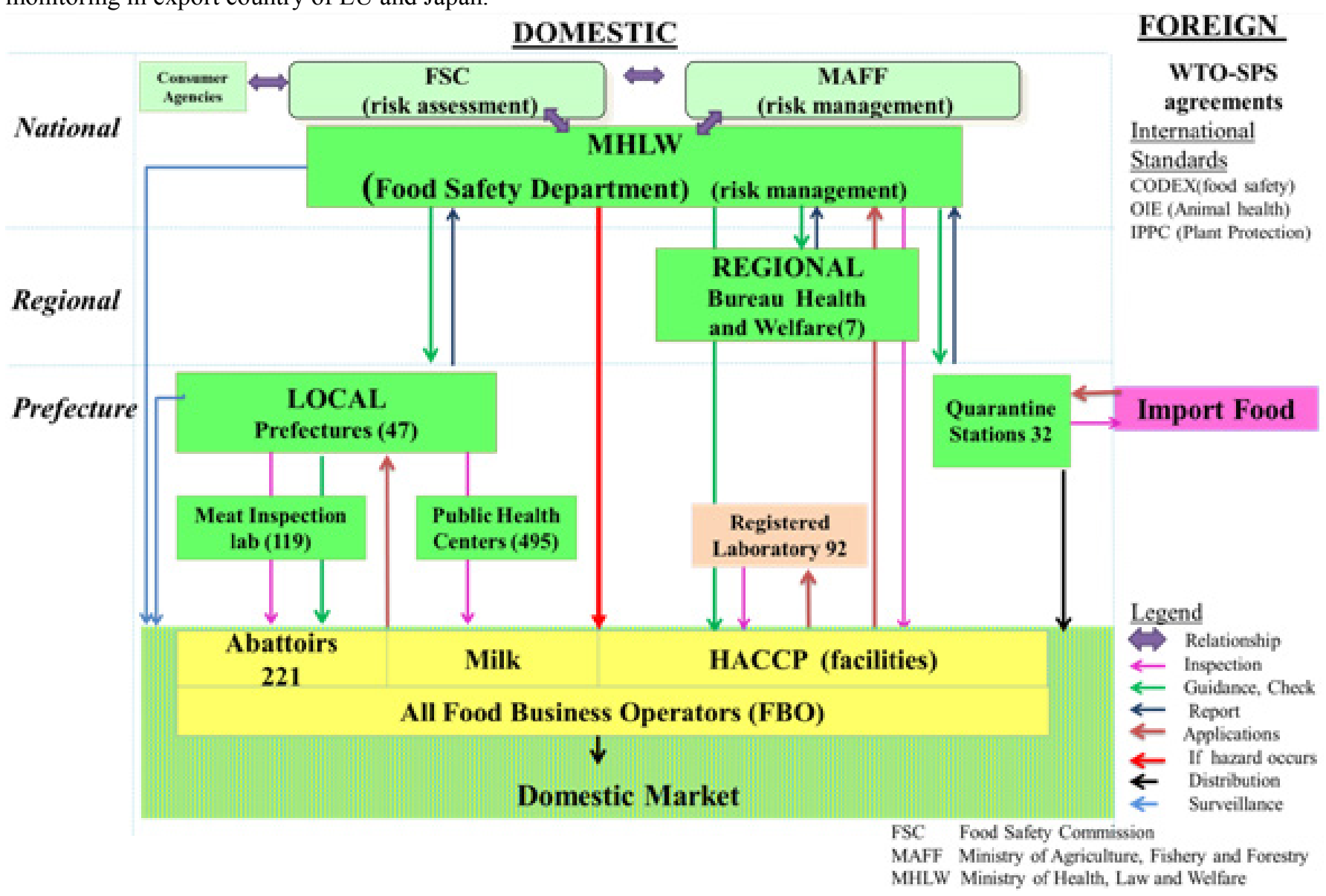

\subsection{Import Food Monitoring in Japan}

This section comprises of three parts (1) regulatory framework and related organizations for monitoring of import foods (2) import food monitoring at quarantine stations and (3) national standards for technical reference.

\subsubsection{Regulatory Framework and Related Organizations for Import Food Monitoring}

In Japan, the first Food Sanitation Law was promulgated in 1947. It covers all aspects of safety of all types of foods, containers and packages and toys in consideration of human health [17]. It was amended in 2003 to give guidance to the Food Safety Basic Law that is the foundation of the responsibility of all three primary stakeholders: government, food business operators (FBO) and consumers. According to the Food Safety Basic Law [9], government (local/State) must implement policy for ensuring food safety, food business operators need to corporate policy implementation and consumers have to endeavor to improve their knowledge and to express their opinion on the policies. Moreover, the introduction of positive list system for farm chemical residues, the introduction of approved facilities in 2003, launchings of Food Safety Commission FSC in 2003 and Consumer Agency in 2009 and so on were established.

Source: Elaborated from the MHLW

Figure 1. Food safety administration of Japan 
Table 1. Six Measures of MHLW for Safety

\begin{tabular}{|l|l|l|l|}
\hline No. & \multicolumn{1}{|c|}{ Name of Measure } & \multicolumn{1}{|c|}{ Act/Law } & \multicolumn{1}{c|}{ Actions taken and Others } \\
\hline 1 & Narcotic & $\begin{array}{l}\text { Narcotics and Psychotropic control Act } \\
\text { Opium Act, Cannabis Act, } \\
\text { Stimulants Control Act }\end{array}$ & $\begin{array}{l}\text { Prefecture level plays the role } \\
8 \text { departments,3 branches nation-wide }\end{array}$ \\
\hline 2 & Water Quality & Water Supply Act & $\begin{array}{l}\text { Both public and private water suppliers need to } \\
\text { report to MHLW }\end{array}$ \\
\hline 3 & Chemical Substances & $\begin{array}{l}\text { Evaluation of Chemical substance } \\
\text { Manufacturing Act }\end{array}$ & $\begin{array}{l}\text { Obligation to dealers, prohibition to other uses } \\
\text { must be in line with the technical guidelines } \\
\text { instructions }\end{array}$ \\
\hline 4 & Household Products & $\begin{array}{l}\text { Control of Household Products } \\
\text { containing harmful substances Act, } \\
\text { Consumer product safety Act }\end{array}$ & $\begin{array}{l}\text { Consumer can complain and consult directly to } \\
\text { prefecture offices that can also support to dealers } \\
\text { and importers }\end{array}$ \\
\hline 5 & Environmental Health & $\begin{array}{l}\text { Environmental Health Industry Act } \\
\text { Business Area Adjustment Act } \\
\text { Japan Finance Corporation Act }\end{array}$ & $\begin{array}{l}\text { Incentives(subsidy, tax reduction) } \\
\text { Adjustment of large-size enterprise (excessive } \\
\text { competition) Environmental sanitation inspectors }\end{array}$ \\
\hline 6 & Quarantine & $\begin{array}{l}\text { Food Sanitation Act } \\
\text { Food Safety Basic Law (2003) }\end{array}$ & $\begin{array}{l}\text { 32 Quarantine stations } \\
\text { 406 Sanitation inspectors (as of 2015) }\end{array}$ \\
\hline
\end{tabular}

Source: elaborated from MHLW

At the national (central) level, the MHLW is the food authority and municipal governments are also responsible at the prefecture level. Narcotic measures, water quality measures, chemical substances safety measures, household products safety measures, environmental health measures and quarantine measures are the six measures of the MHLW for all safety, as described in table (1). Every measure has its act and responsible branches of the MHLW and its own management practices that cover all aspects of safety for drug, water, chemical substances, environmental and food. Among other measures, the quarantine measure is the main measure to examine food safety in Japan in this paper.

The inspection system of food was introduced in 1952 according to the Food Sanitation Law [13]. The law mandates the MHLW to formulate guidelines for the monitoring and guidance on food sanitation to be implemented by the State, under Article 22. Japan has its own guidelines based on risk analysis for ensuring sanitation. The law calls for the MHLW to establish "A guidance plan: imported foods monitoring and guidance plan at National level" for import food, additives, apparatus, and container and packaging, by promoting intensive, effective and efficient import inspections and monitoring and guidance of importers, for every fiscal year, according to Article 23.

\subsubsection{Quarantine Station: Import Food Monitoring}

At the prefecture level, Article 24 obligates the prefectural governor to establish prefectural plan for the monitoring and guidance on food sanitation in accordance with the guidelines established by the MHLW. Food both from domestic and imported supply must be monitored at prefectural quarantine stations under the direct control of the MHLW. It is important to note that quarantine stations are geographically situated at prefectures across Japan but under direct management of the MHLW.

It is widely known that Japanese consumers are among the most health conscious consumers [1]. So, the main focus of this study is to examine how food authority provides import food monitoring system efficiently. Import foods in Japan are classified under six categories such as (1) livestock and processed livestock, (2) aquatic and processed aquatic food, (3) agricultural food and processed agricultural food, (4) food additives, (5) foods subject to enhanced inspection and (6) other foods. Based on the types of foods, six types of testing are generally required such as antibiotics, residues of agricultural chemicals-pesticides, additives, standards for constituents, mycotoxins, GMO.

Governed by the MHLW, three measures are being executed in ensuring safety of import food such as (1) measure at exporting country,(2) measure at the time of import and (3) measure in domestic[13].

\subsubsection{Measures at Export Country}

In export country, the advance consultation service and the promotion of sanitation measures are two measures for import food safety for Japan. Before submission of notification form to the MHLW, exporters to Japan can get advance consultation service provided by the competent government agency of the export countries or the official laboratory designated by the MHLW. There were about 4345 laboratories in 62 foreign countries for consultation, as of 2015[11]. More than half (53\%) 2288 official laboratories belonged to governments.

Japan requests exporting governments to establish sanitation control measures for the promotion of stronger control and monitoring systems for agricultural chemicals, etc., and pre-export inspections, through bilateral talks and on-site inspections. 


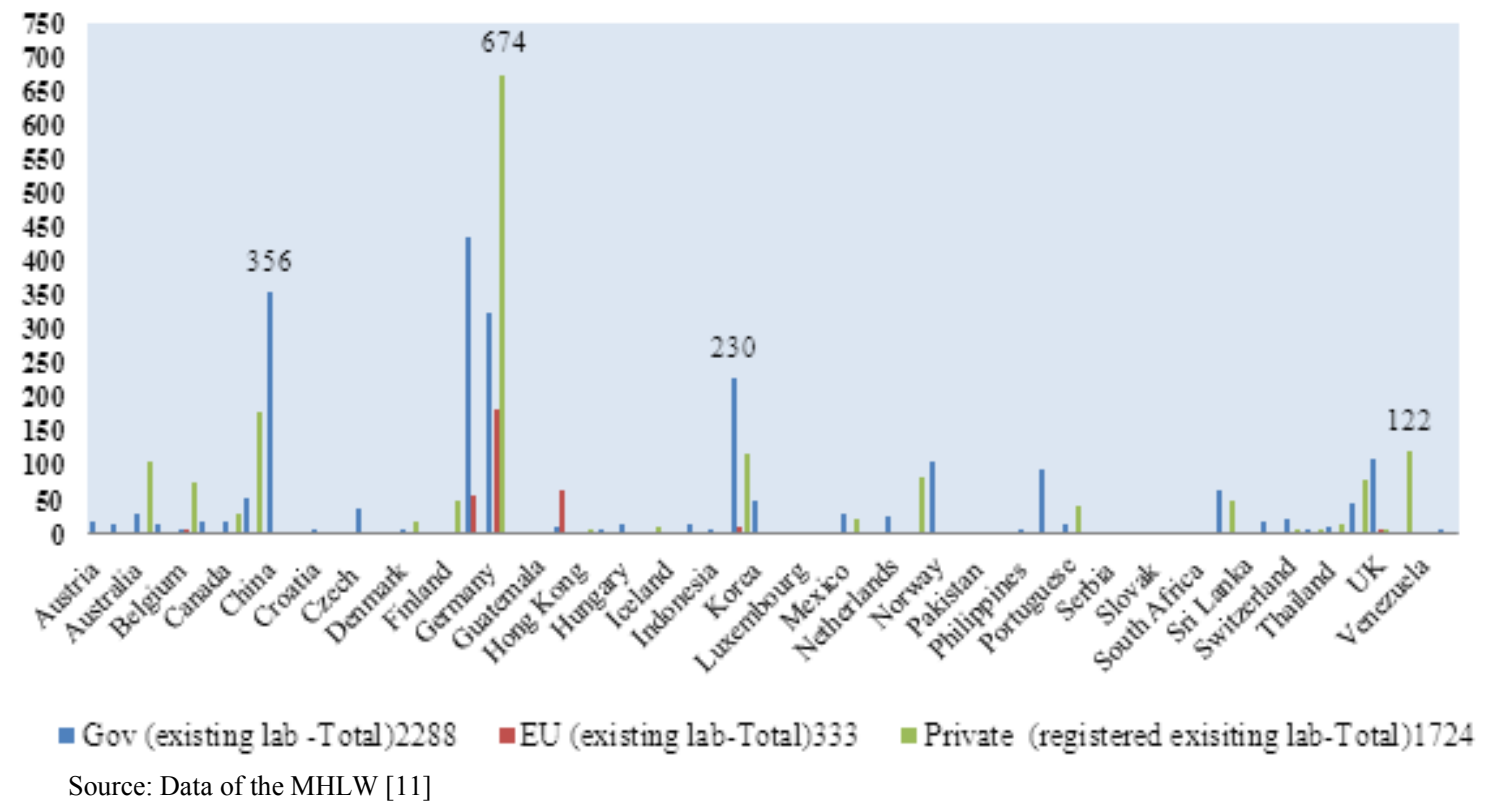

Figure 2. Three types of delegated official laboratories in 62 countries

\subsubsection{Measures at the Time of Import}

Import food inspection is one of the two main functions of quarantine stations. An interview with the official of the Hiroshima quarantine station was made in July, 2015. Submission of "Import notification" to a quarantine station of the MHLW is mandatorily required under Article 17 of the Food Sanitation Law. It is through on line application- food automated import inspection and notification system (FIANS) or paper-based application, so as to carry out document examination and inspection by food sanitation inspectors to see if the import foods comply with the law. Calculated based on the MHLW's data of last thirty one years, a strong positive correlation between the declaration number and the inspection number was found with $\mathrm{r}=0.883$, $\mathrm{n}=31, \mathrm{p}=0.000$.

There were 406 food sanitation inspectors across 32 quarantine stations in Japan. After receiving the notification form, food sanitation inspectors inspect the commercially imported food products with two tiers of inspections: document examination and physical inspection based on the declared information.

Document checking mainly focuses on country of export, import food item, manufacturer, place of manufacturer, ingredients and materials, method of manufacturing, additives used to examine and confirm whether the import food complied with the manufacturing standard, additives standards, etc. under the Food Sanitation Law [10]. According to the interview, four main elements are inspected in document checking such as (1) sanitary health certificate (2) standard requirements (3) official notices from the MHLW and (4) notices from foreign countries.

Depending on potential violation, four levels of physical checking are formulated (1) monitoring inspection (2) other monitoring inspection, (3) inspection order and (4) comprehensive ban. Public and private laboratories share import foods testing tasks depending on the type of inspection based on the document checking and priority items of the MHLW's guidance.

Monitoring inspection and other monitoring inspection fall under a conventional administrative inspection conducted by quarantine stations. Thus importers do not need to wait at the port of arrival while testing the import foods. However, if there is something wrong with the quality of foods, the distribution will be stopped and recall will be made. So it is categorized as a monitoring inspection. Testing the food quality and inspection are done by quarantine stations: the Public administrative agency. Testing takes about a week for getting the result. If there is a problem, then it will take more than a week, according to the interview.

Introduced in 1995, inspection order is to be executed by the registered institution: a private testing company at the expense of importers [13]. It is required if the import food includes in the list of official notices (issued for the food items which are highly expected to commit a violation) of the MHLW. 150 private laboratories were delegated by the MHLW across Japan, as of 2014. Situated in Yokogawa, Hiroshima Kenkakyo Hoken Kyokai is the private laboratory delegated by Hiroshima quarantine station, according to the interview.

In this regard, testing tasks of laboratory service play the role in ensuring import food safety. 4345 foreign laboratories as well as 103 domestic private testing companies are sharing the task with the MHLW, food authority that approves by registration to delegate the testing task to these accredited private companies. Japan Frozen Foods Inspection Corporation (JFFIC) is one of the five biggest private inspection and testing companies among 103 companies inside Japan. Therefore, in terms of the number of testing laboratories, the delegated laboratories in foreign countries outnumbered 42 times higher than that of the domestic laboratories. In terms of the testing function, the 
average percentage of import food testing by the quarantine station, the domestic private laboratories and the delegated foreign laboratories are $32 \%, 58 \%$ and $10 \%$, respectively. Even though the number of the delegated foreign laboratories is the highest, they shared only $10 \%$ of total testing of the import food. As regard with the private testing laboratories, they just need to test the import food inspected by order of the MHLW. However, the final decision whether rejection or not, is made by the quarantine station of the MHLW.

Figure (3) shows the percentage of the import foods tested for Japan by 3 different types of laboratories during last thirty-one years.

\subsubsection{Measures at Domestic}

The preliminary consultation of the MHLW given to importers is to reduce violation rate at port of arrival and to ensure food safety with food chain approach. Decreasing violation rate is a quantifiable indicator to examine the effectiveness of the import consultation. Of 32 quarantine stations, 13 can provide the consultation on import foods.

There was a strong negative correlation between the consultation and the violations rates of import food with $\mathrm{r}=-0.785, \mathrm{n}=8, \mathrm{p}=0.021$, based on the correlation analysis of the data of the table (2). It means that the more consultation importers got before import, the lesser the violation rate at the port of arrival. The MHLW guides importers how to deal with import food safety effectively.

Effective food control systems are vital in enabling countries to assure safety and quality of food products for international trade and to verify that imported food products meet national requirements [5].Data on import detention and rejections support the importance of a strong food import control system for preventing the dumping of lesser quality food [9].

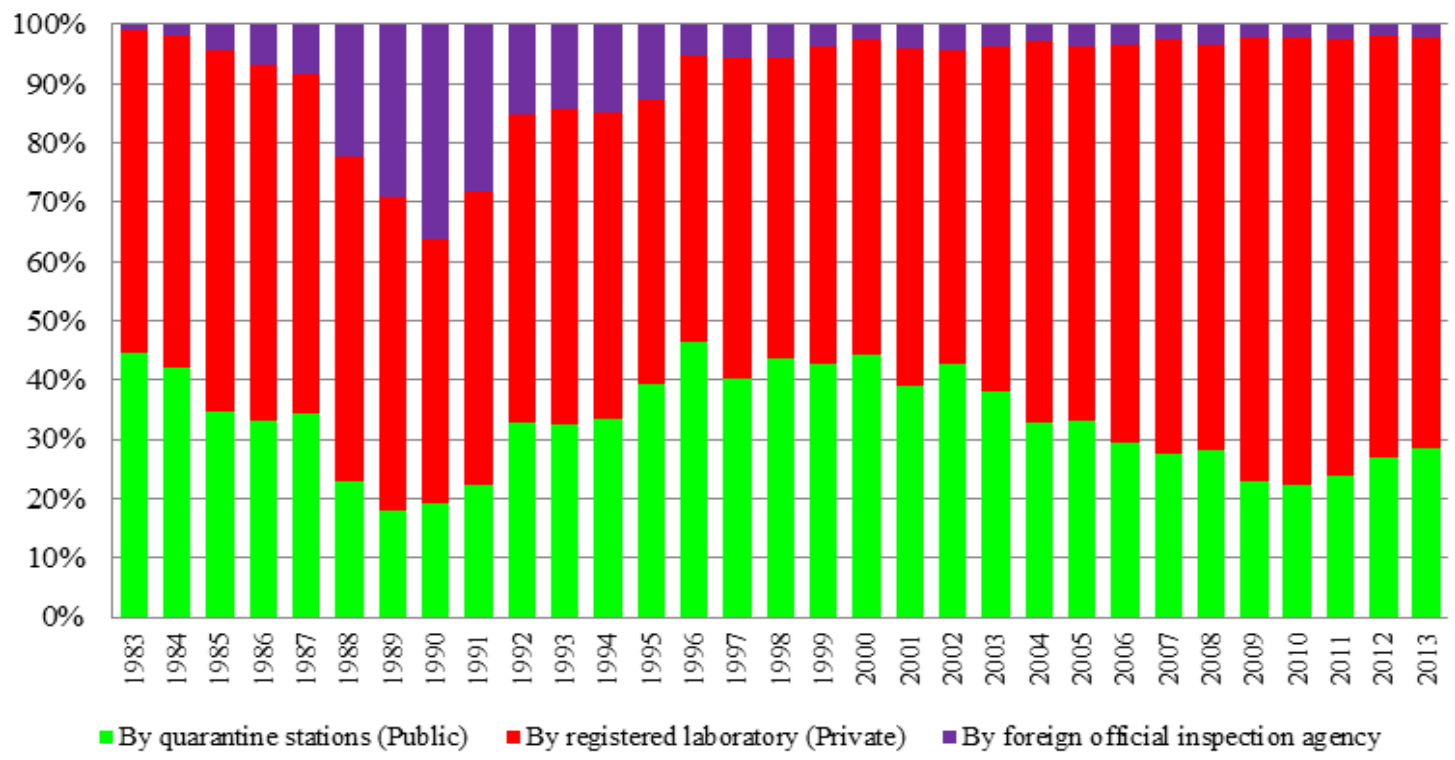

Source: Data from the MHLW [11]

Figure 3. Import food testing at three types of food control laboratories

Table 2. Declined violation with increased consultation

\begin{tabular}{|l|c|c|c|c|c|c|c|c|c|}
\hline & 2005 & 2006 & 2007 & 2008 & 2009 & 2010 & 2011 & 2012 & Trend \\
\hline $\begin{array}{l}\text { Import consultations } \\
\text { implemented }\end{array}$ & 9,210 & 9,786 & 10,633 & 11,601 & 13,275 & 14,324 & 15,122 & 13,962 & Increased \\
\hline $\begin{array}{l}\text { Violations on } \\
\text { item-by-item basis }\end{array}$ & 691 & 679 & 401 & 410 & 310 & 426 & 354 & 372 & Decline \\
\hline
\end{tabular}

Source: Data collected from annual statistical books of the MHLW

Table 3. Major causes of violations

\begin{tabular}{|c|c|c|c|c|c|c|c|c|c|c|}
\hline \multirow{2}{*}{ Causes of Violations } & \multicolumn{9}{|c|}{ Years } & Average \\
\cline { 2 - 13 } & $\mathbf{2 0 0 4}$ & $\mathbf{2 0 0 5}$ & $\mathbf{2 0 0 6}$ & $\mathbf{2 0 0 8}$ & $\mathbf{2 0 0 9}$ & $\mathbf{2 0 1 0}$ & $\mathbf{2 0 1 1}$ & $\mathbf{2 0 1 2}$ & $\mathbf{2 0 1 3}$ & \\
\hline I. Non-compliance with Standards & 66.7 & 64.7 & 66.1 & 69.1 & 51.7 & 53.8 & 58.8 & 59.4 & 52.4 & 60.3 \\
\hline II. Contamination & 11.7 & 14.6 & 21 & 20.9 & 30.9 & 28.4 & 27.1 & 27.7 & 31 & 23.7 \\
\hline III. Food additives & 14 & 16.2 & 10.8 & 5.3 & 4.5 & 7.9 & 6 & 6.4 & 9 & 8.9 \\
\hline IV. Packaging materials & 3.3 & 3.8 & 1.9 & 3.5 & 9.8 & 8.6 & 6.3 & 5.1 & 5.2 & 5.27 \\
\hline V. No attached health Certificate & 3.6 & 0 & 0 & 0.6 & 0.2 & 0.1 & 0.4 & 0.4 & 1.8 & 0.78 \\
\hline VI. Possible risks to human health & 0.7 & 0.5 & 0.2 & 0.7 & 2.9 & 1.3 & 1.4 & 0.6 & 0.6 & 0.99 \\
\hline
\end{tabular}

Sources: Calculation based on annual statistical books of the MHLW 
Every year, the most frequently violated case related with Article 11 of the Food Sanitation Law concerning non-compliances of established standards, specification of food products and process standards found more than 60 percentage on average. It suggested that export country need to focus on compliance with standards to be able to export successfully to lucrative markets like Japan. The second most frequently violated cause was related to the contamination with hazardous or toxic substances such as aflatoxin with average percentage of 24.It is also a violation under Article 6 of the Law.

Figure (4) mentioned three import monitoring measures in Japan, mainly focusing on the second measure: the quarantine station's import food monitoring.

It was found that the scope of Japanese import food control covers (1) giving guidance to importers inside Japan and (2) providing consultation to exporters to Japan, with food-chain approach for some selected import food items. The amount of the actual physical inspection at quarantine station is about 11 percent of the all import food declared, according to calculation based on the last 31 years data. This means that about $89 \%$ of the import food required document checking only, as illustrated in figure (4). According to the interview at the JFFIC, it was stressed that $11 \%$ of physical checking was risky. On the other hand, Japan still follows globally accepted risk-based inspection in document checking such as food specific, country-specific, monthly report, classification of foods such as genetically modified organisms, organic, etc., using code of manufacture, exporters, administrative penalties, manufacturing process etc.

\subsubsection{National Standard for Technical Reference}

In Japan, the Food Safety Basic Law No.233 of 1947 mandates risk management activities of the MHLW and Ministry of Agriculture, Fishery and Forestry (MAFF) to establish standards and guidelines and to launch various branch offices for the enforcement of their regulation [16]. Administered by the MHLW, Article 11 of the Law provides standards required for food and additives in terms of processing method, ingredients and the mandatory labelling system. It also stipulates the procedures to investigate food poisoning causes and to report investigation results for preventing public health risks arising from human consumption of food [3].Having these standards are advantageous in monitoring import food from health and trade perspectives. It was disputed by Chinese vegetable exporters to Japan that Japanese food standards were stricter than necessary after the introduction of the positive list system in Japan [18]. However, Shi [15] argued that as long as the standards formulation method in Japan is in accordance with the internationally accepted norms, exporters like the Chinese needed to improve food safety regulation of export item to Japan by taking the counter measures as soon as possible.

At document checking, the very beginning stage of the inspection, the compliance with standards is considered priority in judging the import foods safety. With the technological advancement, food export country can assure food safety with a number of food safety management system (FSMS) designed for product standards and processing standards. It results that relying on document checking becomes possible nowadays. Table (3) shows evidently that the highest major causes of violation in import food is related with non-compliance with standards.

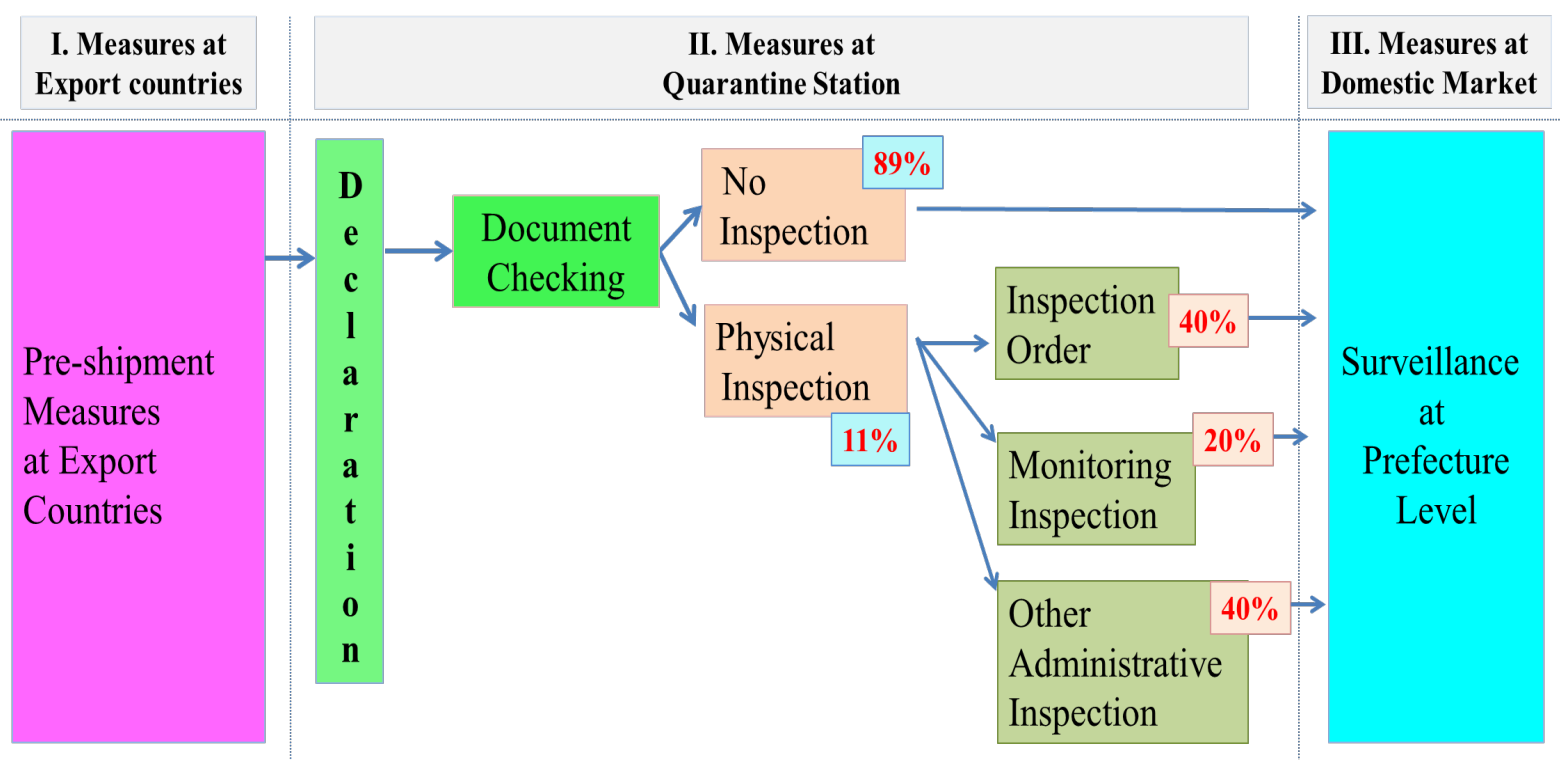

Source: Authors' calculation using the MHLWs' statistical annual data

Figure 4. Three measures for import food safety in Japan 


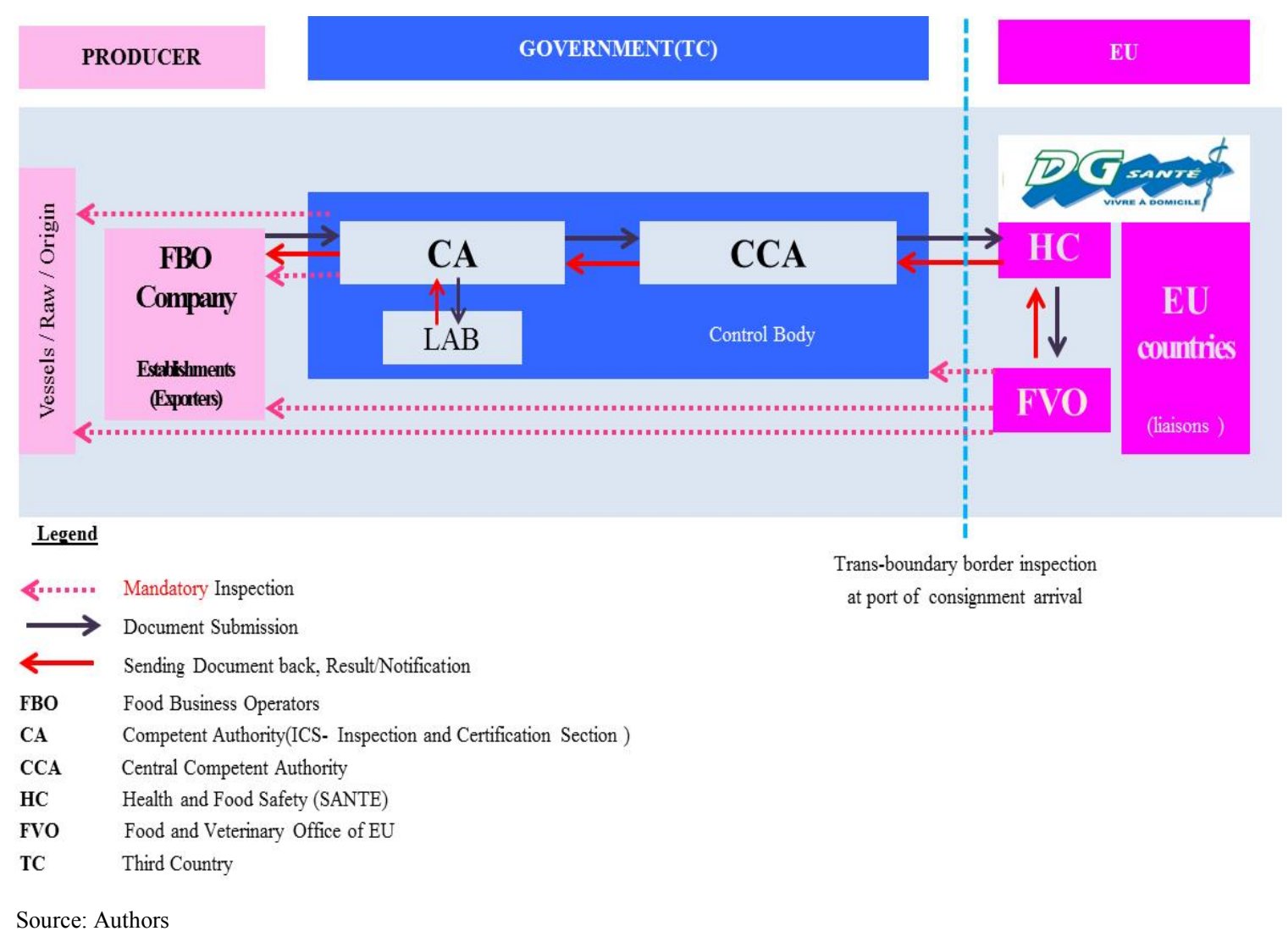

Figure 5. EU's export monitoring in export countries

\subsection{Comparison between EU's Import Food Monitoring in Export Country and Japan}

In this section, the comparison of EU's import food monitoring in export countries and that of Japan is discussed. In this regard, Sanitary and phytosanitary SPS and Technical Barrier to trade TBT Agreements of WTO give guidance as an international legal framework. Article 4 of the SPS Agreement states how recognition agreement could be made between trading partner countries to account for equivalence level in inspection, testing and other relevant procedures. Article 6 of the TBT Agreement mentions how central government bodies of trading partner countries achieve mutual recognition of conformity assessment through accreditation.

In monitoring exportable products to EU markets, the competent authority (CA) of EU: the director general for health and food safety (DG-SANTE) deals only with the competent authority in the export country (also called the third country). As shown in figure (5), the scope of the EU's import food monitoring in the third countries covers along export food-chain. It is governed by the control body of competent authority in export countries and that is mandatorily required for consumers in EU markets. Therefore, there is a national list of approved processing factories controlled by the CA of the export country and only the listed approved factories are eligible to export to EU markets. The export products of the factory are again inspected at ports of arrival. As for the inspections on the CA's control body of the export country and the factory, food and veterinary office (FVO) performs on behalf of the competent authority of EU.

The regulatory environment of EU provides a wider range of cost-effective opportunities by closer collaboration between regulatory agencies and producers, while putting the safe food production responsibility on producers [2].

As regard with the Japanese import food monitoring system, the interaction between the MHLW and export country's CA is not strictly required like the EU system. Instead the MHLW trained importers that have direct and free contact with the exporters or producers in the export countries. As previously mentioned, there are three types of official laboratories in foreign and among them only about half of $(53 \%) 2288$ official laboratories belonged to governments. These two points are main differences between systems of EU and Japan. Figure (6) illustrates the interaction between the MHLW and export country's CA, and the relation between business to business (ExportersImporters) as follows: 


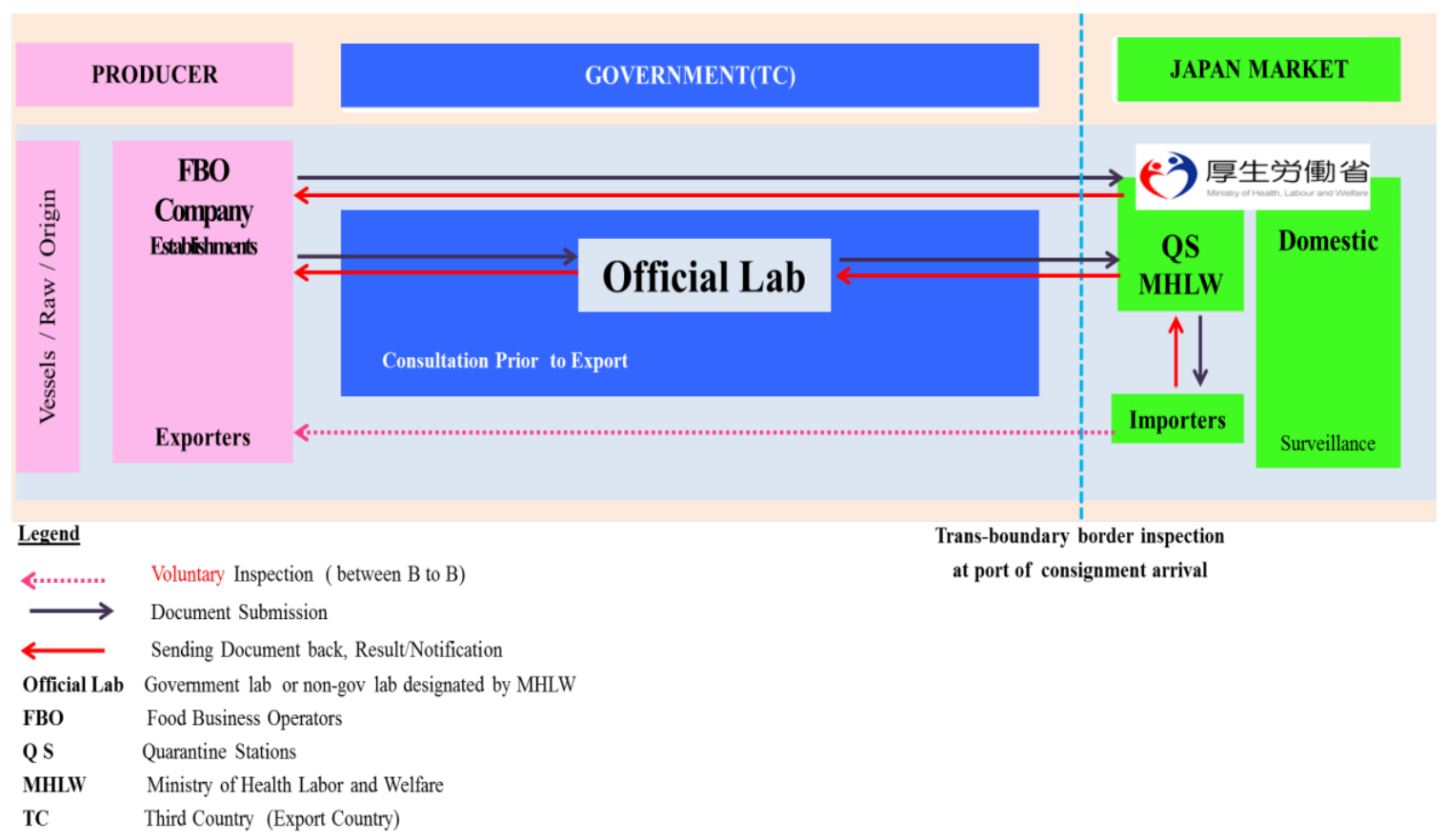

Source: Authors

Figure 6. Japanese import food monitoring in export countries

The inspection conducted by Japanese importers at the export country is just on voluntary basis, as described in figure (6). It can be observed that Japan believes the role of the importers as being crucial in achieving import foods safety. It puts the responsibility also in the hands of importers governed by respective regulations and laws [12].

If comparing with the EU's import food monitoring system that provides the highest level of food safety in the world, Japan has less advantage in terms of scope and food items. According to the interview with the official of the Hiroshima Quarantine Station, it was reported that Japan did not demand from the competent authority of the export country like EU system (in terms of mutual recognition agreement (MRA),etc.), with the exception of some foods.

In fact, Japan also restructured in consort with the 2009 food safety reform of EU. Japan starts taking investigation on food control systems of exportable items in some export countries in 2009. It is a new preventative approach for Japan that covered 27 investigations so far, even though it could not cover all import food yet.

\section{Conclusions}

In the context of a growing concern of Japanese consumer particularly on import food safety, the food authority takes continuous restructuring of import food monitoring system aimed at protection of consumers against adulterated imported food.

Japan's import food monitoring is streamlined in accordance with the globally accepted EU's system. However, Japan chooses not to rely on the competent authority of export country solely resulting that Japanese importers get more choices among producers of export countries.As regard to sharing responsibilities between public and private agencies, it was found that Japan allocated its resources at best. Testing susceptible imported foods is carried out by private testing institutions at the expense of importers. Meanwhile the food authority pays more attention on regular import food monitoring with rigorous document checking, inspection at ports of arrival, standardization, riskmanagement and other surveillances activities of food control measures.

The case study of Japanese import food control shows clearly that it is viable to achieve import food safety, as long as government sets up efficient food control monitoring system supported by national standards with sound quality infrastructure.

\section{Acknowledgements}

The authors would like to express the deepest thanks to all the key informants who participated in the interview research.

\section{REFERENCES}

[1] Agriculture and Agri-food Canada. The Japanese consumer behavior, attitudes and perceptions towards food products. Market analysis report of International markets bureau.2010.

[2] M.G.Martinez,.A.Fearne,.J.A.Caswell,.S.Henson,.Co-regulat ion as a possible model for food safety governance: Opportunities for public-private partnerships. Food Policy.Vol.32, 299-314.2007. 
[3] Online available:http//A.Hironaka,Y.Kawabata,T.Haruyama, Japan:Introduction to the product liability framework.2014, On line available from: https://www.jurists.co.jp/ja/publiccat ion/tractate/docs/prljapa n_201401.pdf.

[4] Online available: http//De Silva D.A.M., Value chain of fish and fishery products: origin, functions and application in developed and developing country markets, Online available from: http://www.fao.org/fileadmin/userupload/fisheries/doc s/VALUECHAIN-repo rt1.doc.

[5] Online available: http//Food and Agriculture Organization/World Health Organization, Assuring food safety and quality: guidelines for strengthening national food control systems, Online available from: http://www.wpro. who.int/foodsafety/documents/docs/English_GuidelinesFo od_control.pdf.

[6] Online available: http//Food and Agriculture Organization, Strengthening national food control systems: A quick guide to assess capacity building needs, Online available from: http://www.fao. org/3/a-a1142e.pdf.

[7] Online available: http//P.Greenhalgh, Sanitary and Phyto-Sanitary SPS Measures and Technical Barriers to Trade TBT, Online available from: http://projects.nri.org/ fishtrade/issues-sanitary.pdf.

[8] Online available: http//M.Kenny, International food trade: food quality and safety considerations, Online available from: http://www.fao.org/docrep/w9474t/w9474t02.html.

[9] Online available: http//Ministry of Health, Labour and Welfare, Food Safety Basic Law, Online available from: http: //www.fsc.go.jp/sonota/fsb law1807.pdf.2003.

[10] Online available: http//Ministry of Health, Labour and Welfare, Imported food safety, Online available from: http://www.mhlw.go.jp/english/topics/importedfoods/ index. html.

[11] Online available: http//Ministry of Health, Labour and Welfare, List of official laboratory, Online available from: http://www.mhlw.go.jp/English/topics/importedfoods/1-10.h tml.
[12] Online available: http//Ministry of Health, Labour and Welfare, Inspection results of the imported food monitoring and instruction program in 2006: An interim report, Online available from:http://www.mhlw.go.jp/english/topics/import edfoods/dl/6.pdf.

[13] Online available: http//Ministry of Health, Labour and Welfare, Development of imported foods monitoring and guidance plan for FY 2009, Online available from : http:// ww w.mhlw.go.jp/English/topics/imported foods/09/09-01.html.

[14] Online available: http//Ministry of Health, Labour and Welfare, Statistics of imported foods monitoring for FY 2013, Online available from:http://www.mhlw.go.jp/english/topics /importedfoods/13/d1/ 13-08a.pdf.

[15] Online available: http//M.Shi, Japanese safety standards of imported foods: focus on pesticide residues and organic products, Online available from: http://info.worldbank.org/e tools/docs/library/55383/chinaefa2/chinaefa2/pdf/pptMinjun Shi.pdf.2004

[16] Online available: http//S.Miyagawa, Food regulation on agrochemicals for ensuring quality and safety of food supply in Japan, Online available from: http://www.agnet. org/ lib rary.php?func $=$ view\&style=type\&id $=20110712080621$.

[17] Online available: http//T.Takahashi, Laws and regulations on food safety and food quality in Japan, Online available from: http://www.ab.auone-net.jp/ ttt/food\%20safety\%20in\%20Ja pan.html.2009.

[18] Online available: http//UNIDO, Meeting standards, winning markets: regional trade standards and compliances report East Asia, Online availablefrom:www.unido.org/fileadmin/userm ediaupgrade/Whatwedo/Topics/Quality_and_compliance/U NIDO-IDE-JETRORegionalTSC_Report-EastAsia2013final _ebook.pdf

[19] Online available: http//World Trade Organization, Articles 5.7 of Sanitary and Phytosanitary SPS measures, Online available from:https://www.wto.org/english/rese/bookspe/an alyticindexe/sps02e.htm.

[20] S.Hisano. Food security politics and alternative agri-food initiatives in Japan. Graduate School of Economics, Kyoto University, Kyoto, 2015. 